\title{
Chemical composition and ruminal digestion of corn silage with Morus alba L. foliage
}

\section{Composición química y digestión ruminal del ensilado de maíz con follaje de Morus alba $\mathrm{L}$.}

\section{Regulo Jiménez-Guillén [ (D) David Heriberto Noriega-Cantú1 Saúl Rojas-Hernández 2 [D Jaime Olivares-Pérez ${ }^{2 *}$ (D), Abel Villa-Mancera ${ }^{3}$ (D) Agustín Olmedo-Juárez 4 [D David Paredes-Díaz 1 (D) Humberto Hernández-Hernández 10}

${ }^{1}$ Centro de estudios profesionales del CSAEGRO y Colegio superior agropecuario del estado de Guerrero. Km 14.5, Iguala-Cocula Gro, México CP. 39200.

${ }^{2}$ Facultad de Medicina Veterinaria y Zootecnia, Universidad Autónoma de Guerrero. Km. $\quad 3.0$ carretera Altamirano-Iguala. CP. 40660, Pungarabato, Ciudad Altamirano, Guerrero, México.

${ }^{3}$ Facultad de Medicina Veterinaria y Zootecnia-Benemérita Universidad Autónoma de Puebla. Km. 7.5 Carretera Cañada Morelos. CP. 75470. El Salado, Tecamachalco, Puebla, México.

${ }^{4}$ Instituto Nacional de Investigaciones Forestales, Agrícolas y PecuariasCENID-PAVET.

*Corresponding author: olivaares@hotmail.com

Scientific article Received: April 08, 2019 Accepted: September 06, 2019

How to cite: Jiménez-Guillén $R$, Noriega-Cantú DH, Rojas-Hernández $\mathrm{S}$, Olivares-Pérez J, Villa-Mancera A, Olmedo-Juárez A, Paredes-Díaz D, Hernández-Hernández H (2020) Chemical composition and ruminal digestion of corn silage with Morus alba L. foliage. Ecosistemas y Recursos Agropecuarios 7(1): e2228. DOI: 10.19136/era.a7n1.2228
ABSTRACT. Chemical composition and ruminal digestion parameters were measured in the silage of the whole corn plant (Zea mays L.) mixed with mulberry foliage (Morus alba L.) in ratio of 100:0, 80:20, 60:40, 40:60, 20:80 and 00:100\% of fresh forage weight, respectively. The 40:60 ratio of corn: mulberry increased crude protein content $(C P=14.28 \%)$ and decreased hemicellulose $(12.15 \%)$, neutral $(\mathrm{NDF}=28.00 \%)$ and acidic (ADF $=15.85 \%$ ) detergent fiber, compared to $100: 0 \%$ ratio, respectively, which led to a $21.3 \%$ increase in in vitro dry matter digestibility (IVDMD). Also ammoniacal nitrogen $7.40 \%\left(\mathrm{NH}_{3}-\mathrm{N} /\right.$ total $\left.\mathrm{N}\right)$ was higher in the ratio $40: 60 \%$, with $\mathrm{pH}$ of 4.19 which is normal for silages, which translates the buffer activity correct of ammonia and its importance for silage fermentation stability. The correlation $(r=0.61, p<0.001)$ indicated that at higher CP content, higher is IVDMD and hemicellulose $(r=-0.99)$, ADF $(r=-0.98)$ and NDF $(r=-0.98)$ indicated that these fibrous compounds decreased IVDMD $(p<0.001)$. The regression showed that the increase in content CP $(0.555 \%, p<0.01)$ and IVDMD $(0.3391 \%, p<$ $0.001)$ with the decrease of NDF $(-0.3526 \%)$, ADF $(-0.1623 \%)$ and hemicellulose $(-0.1903 \%)(p<0.001)$ in mixed mini silos, was attributed to mulberry foliage addition. It is concluded that the contribution of dry matter and nitrogen of mulberry, decreased the fiber content and increased digestibility parameters of silage when it is elaborated in ratio of 40:60 corn and mulberry, respectively.

Key words: Mulberry, association crops, silage, digestion parameters, ammoniacal nitrogen, lag time.

RESUMEN. La composición química y los parámetros de digestión ruminal se midieron en el ensilado de la planta completa de maíz (Zea mays L.) mezclada con follaje de morera (Morus alba L.) a proporciones de 100:0, 80:20, 60:40, 40:60, 20:80 y 00:100\% de forraje en peso fresco, respectivamente. La proporción 40:60 de maíz: morera aumentó el contenido de proteína cruda (PC $=14.28 \%)$ y disminuyó la hemicelulosa $(12.15 \%)$, fibra detergente neutra (FDN $=28.00 \%$ ) y ácida (FDA $=15.85 \%$ ), en comparación con 100: 0\%, respectivamente, lo que condujo a un aumento del $21.3 \%$ en la digestibilidad in vitro de la materia seca (DIVMS). Además, el nitrógeno amoniacal 7.40\% ( $\mathrm{NH}_{3}-\mathrm{N} / \mathrm{N}$ total) fue mayor en la proporción 40:60\%, con un $\mathrm{pH}$ de 4.19 normal para ensilajes, lo que traduce la correcta actividad tampón del amoníaco e importancia para la estabilidad fermentativa del ensilado. La correlación $(r=0.61, p<0.001)$ indicó que a mayor contenido de $\mathrm{PC}$, mayor fue la DIVMS y hemicelulosa $(r=-0.99)$, FDA $(r=-0.98)$ y FDN $(r=-0.98)$; lo que indica que estos compuestos fibrosos disminuyeron la DIVMS $(p<0.001)$. La regresión indica aumento en el contenido de PC $(0.0555 \%, \mathrm{p}<0.01)$ y DIVMS $(0.3391 \%$, p $<0.001)$ con la disminución de FDN $(-0.3526 \%)$, FDA $(-0.1623 \%)$ y hemicelulosa $(-0.1903 \%)(p<0.001)$ en mini silos mixtos, se atribuyó a la adición de morera. La contribución de la materia seca y nitrógeno de la morera, disminuyó el contenido de fibra y aumentó los parámetros de digestibilidad del ensilaje cuando se elaboró en una proporción de 40:60 de maíz y morera, respectivamente.

Palabras clave: Morera, cultivos asociados, ensilado, parámetros de digestión, nitrógeno amoniacal, tiempo lag. 


\section{INTRODUCTION}

The tropical zones where a great part of the animal production takes place, have an annual season of no rainfall with a decrease in the quantity and quality of the forages used as feed in the animal breeding (Macome et al. 2017). Silage, mainly from grasses with high starch content, is a procedure to preserve high quality forages and use them in difficult seasons when feed is scarce (Copani et al. 2016, Khan et al. 2015). The silage nutritional value largely depends on the content and degradability of the starch (Macome et al. 2017). However, materials rich in starch may be deficient in nitrogen compounds such as proteins (Luscher et al. 2014). Based on this, there is an emphasis on the use of protein-rich legume foliage to be added in the silages elaboration (Copani et al. 2016). Although comparatively with grasses, the ensiled legumes are more susceptible to proteolysis due to their higher crude protein content, lower carbohydrate content and greater buffering capacity (Foster et al. 2011). The nutritional value of feed is associated with its chemical composition and the utilization level of nutrients (Behling et al. 2017). Carbohydrates and protein fractions allows the formulation of appropriate diets, enabling maximum efficiency of energy and nitrogen use, both by microorganisms and by the host. Besides the chemical composition, digestibility is a key parameter in the evaluation of forage quality (Behling et al. 2017). Assessment of in vitro gas production (IVGP) is largely used to evaluate the digestibility for feeds in ruminants by incubating substrate in buffered rumen fluid (Dijkstra et al. 2005). In this study silages of corn with mulberry at different proportions were elaborated and the nutritional quality was determined based on the chemical composition, in vitro dry matter digestibility, gas production and in vitro fermentation parameters.

\section{MATERIALS AND METHODS}

The study was conducted in the CSAEGRO professional studies center of Guerrero Mexico between $18^{\circ} 20^{\prime} 52^{\prime \prime} \mathrm{NL}$ and $99^{\circ} 30^{\prime} 24^{\prime \prime} \mathrm{WL}$. The predominant climate is Aw0 (dry warm) with 1045 $\mathrm{mm}$ average annual precipitation and temperature between 18 and $44{ }^{\circ} \mathrm{C}$. The soils are clayey texture, slightly compact, with $1 \%$ of organic matter and $\mathrm{pH}$ of 7.9 to 8.2 .

\section{Treatments and silages elaboration}

The study lasted 71 days (34 days for elaboration and silages fermentation and 37 days for incubation of silage samples), this without counting the time required for the phenological development of crops and time needed for laboratory analysis and assays.

In the silages elaboration, whole corn plants (90 days post-sowing) and leaves of Morus alba (165 days post-regrowth) harvested manually and chopped in a forage mill at $5 \mathrm{~cm}$ screen, were used. With the vegetative material five mini-silos per treatment were elaborated in polyethylene buckets with a capacity of eight kilograms of vegetative material at different proportions (homogeneous mixtures) to form the six treatments (Table 1). During the filling the forage material was manually compacted to expel air content from the bucket and favors the anaerobic fermentation. The buckets were sealed and stored for 34 days in a dark room to decrease air circulation and sunlight.

Table 1. Mixed silages with foliage of Zea mays (complete plant) and Morus alba (leaves) at different proportions as treatments.

\begin{tabular}{|c|c|c|c|c|c|}
\hline \multirow[t]{2}{*}{ Treatments* } & \multicolumn{2}{|c|}{ Zea mays } & \multicolumn{2}{|c|}{ M. alba } & \multirow{2}{*}{$\frac{\text { Total volume }}{\mathrm{Kg}}$} \\
\hline & $\%$ & $\mathrm{~kg}$ & $\%$ & $\mathrm{~kg}$ & \\
\hline T1 & 100 & 8 & 0 & 0 & 8 \\
\hline T2 & 80 & 6.4 & 20 & 1.6 & 8 \\
\hline T3 & 60 & 4.8 & 40 & 3.2 & 8 \\
\hline T4 & 40 & 3.2 & 60 & 4.8 & 8 \\
\hline T5 & 20 & 1.6 & 80 & 6.4 & 8 \\
\hline T6 & 0 & 0 & 100 & 8.0 & 8 \\
\hline
\end{tabular}

\section{Chemical analysis of silages}

From each experimental unit, $500 \mathrm{~g}$ of samples were collected from the center of mini-silo and placed in black polyethylene bags of $2 \mathrm{~kg}$ capacity, wrapped in aluminum foil and kept in freezing at $-15^{\circ} \mathrm{C}$ for 37 days for use in laboratory analysis. The samples were defrost at room temperature and used to measure the hydrogen potential $(\mathrm{pH})$ with a $\mathrm{pH}$ meter (Orion, model 290) on an aqueous extract prepared with $25 \mathrm{~g}$ fraction of silage and $250 \mathrm{~mL}$ of distilled water and an 
incubation time $1 \mathrm{~h}$.

Another sample fraction was dried for $48 \mathrm{~h}$ in a forced air oven at $55{ }^{\circ} \mathrm{C}$ until constant weight and ground in a THOMAS-WILEY mill model 4-(3383L10) with $1 \mathrm{~mm}$ screen. This fraction was used to determine the organic matter, ash, crude protein and ammonium content by the methods 967.03 , $942.05,976.05$ and 999.01 respectively, identified in the AOAC (2000).

The neutral detergent fiber (NDF), acid detergent fiber (ADF) and in vitro dry matter digestibility (IVDMD) were determined through the analytical methods (Van Soest et al. 1991). An Ankom 200 fiber analyzer equipment was used (Ankom Technology Corp.).

The hemicellulose content in the silages was determined with the equation:

$\%$ hemicellulose $=\%$ neutral detergent fiber $(N D F)$

- \% Acid detergent fiber $(A D F)$

\section{In vitro gas production (IVGP)}

Gas production was determined by the method proposed by Theodorou et al. (1994), for which 125 $\mathrm{mL}$ bottles were used for each sample. In duplicate and in three incubation series $1.0 \mathrm{~g}$ of DM of each sample was introduced into the bottle. Subsequently, $100 \mathrm{~mL}$ of buffer solution was added in a $\mathrm{CO}_{2}$ atmosphere. Ruminal fluid was obtained from adult donor sheep fed with diet at a rate of $90-10 \%$ corn silage and concentrate, respectively. Subsequently, the ruminal fluid was kept at $39^{\circ} \mathrm{C}$ under the $\mathrm{CO}_{2}$ atmosphere and filtered through three layers of cheesecloth and $25 \mathrm{~mL}$ were added to each bottle. Finally, the bottles were placed in a water bath at $39{ }^{\circ} \mathrm{C}$ and the measurement of gas production was carried out with a pressure transducer (Ankom RF XBEE PKG from Ankom Technology Corp.). The gas volume produced was measured every $15 \mathrm{~min}$ for 72 $\mathrm{h}$ after the start incubation. For corrections by contamination with ruminal content, two bottles without substrate were used as blanks.

\section{Estimation of fermentation parameters}

The degradability and fermentation kinetics on silages (treatment) were calculated using the model of
Krishnamoorthy et al. (1991) $A=b \times\left(1^{-e-c(t-L a g)}\right)$, where $A$ is the gas volume production at time $t, b$ is the asymptotic gas production milliliter per gram DM, $c$ is the speed the gas produced (h) of fraction $b$ of slowly fermentable food, and $t_{L a g}$ is the starting time of the fermentation of NDF.

\section{Statistical analysis}

The data of the chemical composition variables and in vitro fermentation parameters of silages were analyzed by general linear models of the SAS (2002) and the tukey test $(p<0.05)$ for the comparison of means between silages, under a completely randomized experimental design statistical model: $y_{i j}=\mu+\tau_{i}+\varepsilon_{i j}$ where $\mathrm{y}$ is the response variable to the effect of the $i$-th treatment in the $j$-th repetition, $\mu$ the general mean, $t$ effect of the treatment $i(0,20$, $40,60,80$ and $100 \%$ of $M$. alba foliage) and $\varepsilon$ is the error of the $j$-th repetition within the $i$-th treatment.

A correlation analysis ( $r$ ) was developed among the chemical composition variables of silages (dry matter, ashes, crude protein, neutral detergent fiber, acid detergent fiber and hemicellulose) with $\mathrm{pH}, \mathrm{NH}_{3}$ $\mathrm{N} /$ total $\mathrm{N}$, gas production, IVDMD, lag time and speed of the gas produced (h) of fraction of slowly fermentable feed (c). A regression analysis $\left(r^{2}\right)$ was also developed and the addition of Morus alba foliage this considered as independent variable and as dependent variables the chemical composition and fermentation parameters were considered.

\section{RESULTS}

\section{Chemical composition}

Table 2 describes the chemical composition and in vitro fermentation parameters of corn and $M$. alba silages. In the chemical composition, dry matter, ashes and protein were increased in silages, from 12.14 to $14.79 \%(p<0.0001)$ and from 13.97 to $17.93 \%(p<0.05)$ respectively, for each nutrient, when the foliage of $M$. alba was added to $60 \%$ or higher. In fiber content, a reduction in NDF (from 40.98 to $12.92 \%$ ), ADF (from 40.98 to $12.92 \%$ ) and hemicellulose (from 40.98 to $12.92 \%$ ) was observed in silages from the inclusion of $20 \%$ M. alba foliage ( $p$ 
Table 2. Chemical composition and in vitro fermentation parameters of maize plant silage added with foliage of Morus alba.

\begin{tabular}{lcccccccc}
\hline \multicolumn{7}{c}{ Silages (\%) (Maize plant : Morus alba) } \\
& $100: 0$ & $80: 20$ & $60: 40$ & $40: 60$ & $20: 80$ & $0: 100$ & SEM & P-value \\
\hline Dry matter (\%) & $20.25^{c}$ & $21.88^{b c}$ & $22.50^{b c}$ & $24.00^{b}$ & $30.38^{a b}$ & $35.75^{a}$ & 3.47 & 0.001 \\
Organic matter (\%) & $90.36^{a}$ & $88.97^{a b}$ & $87.86^{b c}$ & $87.26^{c}$ & $85.64^{d}$ & $85.21^{d}$ & 6.40 & 0.001 \\
Ashes (\%) & $9.64^{d}$ & $11.03^{c d}$ & $12.14^{b c}$ & $12.74^{b}$ & $14.36^{a}$ & $14.79^{a}$ & 0.64 & 0.0001 \\
Neutral detergent fiber (\%) & $49.04^{a}$ & $40.98^{b}$ & $32.21^{c}$ & $28.00^{c}$ & $20.31^{d}$ & $12.92^{e}$ & 2.84 & 0.0001 \\
Acid detergent fiber (\%) & $24.70^{a}$ & $21.22^{b}$ & $17.29^{c}$ & $15.85^{c}$ & $11.81^{d}$ & $7.91^{e}$ & 1.58 & 0.0001 \\
Hemicellulose (\%) & $24.35^{a}$ & $19.76^{b}$ & $14.92^{c}$ & $12.15^{c}$ & $8.50^{d}$ & $5.01^{e}$ & 1.41 & 0.0001 \\
Hydrogen potential (pH) & $3.90^{d}$ & $4.02^{c d}$ & $4.07^{b c d}$ & $4.19^{a b c}$ & $4.24^{a b}$ & $4.32^{a}$ & 0.07 & 0.0001 \\
IVDMD (\%) & $56.37^{d}$ & $64.40^{c}$ & $74.65^{b}$ & $77.67^{b}$ & $85.05^{a}$ & $90.79^{a}$ & 2.90 & 0.0001 \\
NH H $_{\text {-N/total N (\%) }}$ & $5.42^{a b c}$ & $5.64^{a b}$ & $5.64^{a b}$ & $7.40^{a}$ & $4.63^{b c}$ & $3.44^{c}$ & 0.87 & 0.0002 \\
Crude protein (\%) & $11.25^{c}$ & $13.65^{b c}$ & $13.97^{b c}$ & $14.28^{b}$ & $15.37^{a b}$ & $17.93^{a}$ & 2.69 & 0.050 \\
Gas production (mL/g DM) & $114.13^{a b}$ & $109.83^{a b}$ & $105.01^{b}$ & $113.15^{a b}$ & $125.93^{a}$ & $119.70^{a b}$ & 8.80 & 0.050 \\
Lag time (h) & $0.044^{c}$ & $0.065^{b}$ & $0.077^{b}$ & $0.105^{a}$ & $0.111^{a}$ & $0.110^{a}$ & 0.008 & 0.0001 \\
Degradation rate (c) (\%/h) & $0.47^{a}$ & $0.61^{a}$ & $1.67^{a}$ & $1.56^{a}$ & $2.00^{a}$ & $2.02^{a}$ & 0.90 & 0.10 \\
\hline
\end{tabular}

$\overline{a b c d e}$ Different literals in the same row indicate statistical differences, tukey test $(\mathrm{p}<0.05) .{ }^{*}$ Lag time: colonization time $\left(\mathrm{h}^{-1}\right)$. IVDMD: in vitro dry matter digestibility. SEM: Standard error of means.

$<0.0001)$. The silage $\mathrm{pH}$ showed a significant variation $(p<0.0001)$ between 3.90 to 4.32 and the variation was attributed to the addition of $M$. alba foliage. In the in vitro fermentation parameters, that the IVDMD was higher in the silages added with $M$. alba foliage was observed, and it showed a proportional increase $(p<0.0001)$ after the $20 \%$ level with $64.40 \%$, until replacing $100 \%$ of the ensiled with $90.79 \%$ digestibility, respectively (Table 2). The ammonia levels did have changes related to the percentages of corn or mulberry in silage mixes, $7.40 \%$ of $\mathrm{NH}_{3}-\mathrm{N} /$ total $\mathrm{N}$ was found in the mixture of 40:60 corn and mulberry, which was different to the observed in mixtures of $20: 80$ and $0: 100$, with 4.63 and $3.44 \%$, respectively $(p<0.0002)$. In vitro gas production was higher $(125.93 \mathrm{~mL} / \mathrm{g} \mathrm{DM})$ in silage with $80 \%$ of $M$. alba and less $(105.01 \mathrm{~mL} / \mathrm{g}$ $D M)$ in silage with $40 \%$ of $M$. alba $(p<0.05)$.

The colonization time (lag time) was greater in all silages added with $M$. alba foliage and varied significantly between 0.065 to $0.111 \mathrm{~h}$, probably due to the greater availability protein substrate mainly attributed to the increase in the levels of mulberry (Table 2).

\section{Association analysis between chemical composi- tion and degradation parameters}

The table 3 shows the correlation between chemical composition and digestion parameters of corn with $M$. alba silages. A strong positive correlation was observed between the dry matter content $(r$
$=0.75$ and $0.65, p<0.001)$, ashes $(r=0.93$ and 0.79 , $p<0.001)$ and crude protein $(r=0.61$ and $0.61, p<$ 0.01 ), with the IVDMD and the $\mathrm{pH}$, respectively, in the silages. Also the dry matter content showed positive correlation with lag time $(r=0.81, p<0.001)$ and the degradation rate $c(r=0.51, p<0.01)$. The correlation of the ash content with the lag time was negative $(r=-0.90, p<0.001)$ and positive with the degradation rate $c(r=0.49, p<0.05)$. On the other hand, the CP showed positive correlation $(r=0.58, p<0.01)$ with gas production (GP) and negative with lag time $(r=-0.57, p<0.01)$. The fiber content (NDF, ADF and hemicellulose) had a negative correlation with the IVDMD $(p<0.001)$, the $\mathrm{pH}(\mathrm{p}<0.001)$, the ammonia nitrogen $(p<0.05)$ and the degradation rate $c(p<$ 0.01 ); but they had a high positive correlation with the lag time $(r=0.87$ to $0.88, p<0.001)$ of the silages.

The regression analysis in figure 1 shows that the reduction in the fiber content of silages (Table 1) is attributed $(p<0.001)$ by more than $90 \%$ to the addition of $M$. alba foliage, by showing negative regressions with the NDF $\left(b_{x y}=-0.3526 ; r^{2}=0.95\right)$, ADF $\left(b_{x y}=-0.1623 ; r^{2}=0.93\right)$ and Hemicellulose $\left(b_{x y}=-\right.$ $\left.0.1903 ; r^{2}=0.95\right)$, respectively. The analysis between the addition of $M$. alba foliage to the silage and the PC and ash contents showed positive regressions of $\mathrm{b}_{x y}=$ 0.0555 and $\mathrm{b}_{x y}=0.00519$, respectively, with values of $r^{2}=0.38(p<0.01)$ and $r^{2}=0.89(p<0.001)$, respectively, which indicated that the increase in the content of these nutrients was attributed to the addition of the 
Table 3. Correlation $(r)$ between chemical composition and digestion parameters of the maize plant silage added with Morus alba foliage.

\begin{tabular}{|c|c|c|c|c|c|c|}
\hline & IVDMD & $\mathrm{pH}$ & $\mathrm{NH}_{3}-\mathrm{N} /$ total $\mathrm{N}$ & GP & Lag time & c \\
\hline Dry matter & $0.75^{\star \star \star}$ & $0.65^{\star \star \star}$ & $0.15^{n s}$ & $0.21^{n s}$ & $0.81^{* \star *}$ & $0.51^{* *}$ \\
\hline Ashes & $0.93^{\star \star \star}$ & $0.79^{\star \star \star}$ & $-0.34^{n s}$ & $0.36^{n s}$ & $-0.90^{\star \star \star}$ & $0.49^{*}$ \\
\hline Crude protein & $0.61^{* *}$ & $0.61^{* \star}$ & $0.19^{n s}$ & $0.58^{* *}$ & $-0.57^{\star *}$ & $0.04^{n s}$ \\
\hline Neutral detergent fiber & $-0.99^{\star \star \star}$ & $-0.87^{\star \star *}$ & $-0.46^{\star}$ & $-0.36^{n s}$ & $0.88^{* * *}$ & $-0.59^{\star *}$ \\
\hline Acid detergent fiber & $-0.98^{\star \star \star}$ & $-0.85^{\star \star \star}$ & $-0.44^{\star}$ & $-0.38^{n s}$ & $0.87^{\star \star \star}$ & $-0.57^{\star \star}$ \\
\hline Hemicellulose & $-0.99^{\star \star \star}$ & $-0.87^{\star \star \star}$ & $-0.47^{*}$ & $-0.34^{n s}$ & $0.88^{\star \star \star}$ & $-0.60^{\star *}$ \\
\hline
\end{tabular}

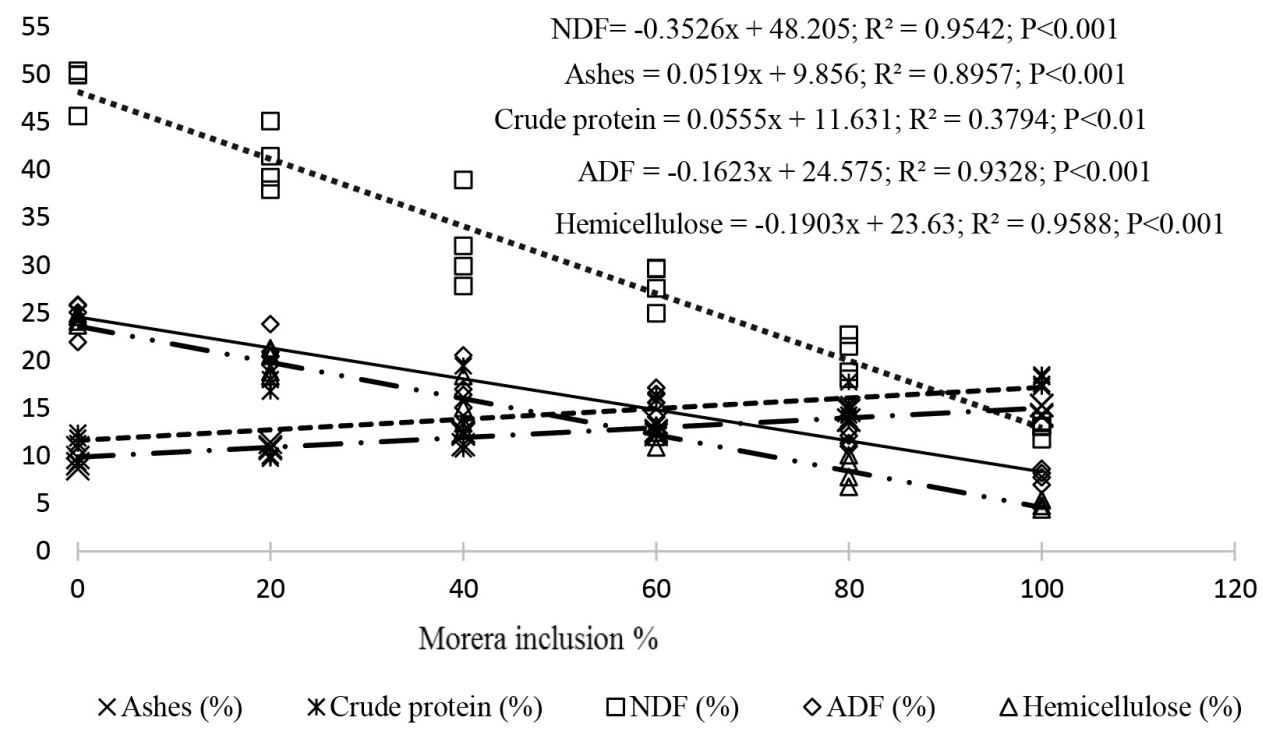

Figure 1. Regression analysis between the addition of Morus alba with the chemical composition of the maize plant silage.

tree foliage.

Figure 2 shows that the $M$. alba addition has positive regression $b_{x y}=0.3391$ with a value of $r^{2}$ $=0.93(p<0.001)$, which indicates that the addition of the tree foliage to the ensiled increased the gas production and the digestibility. Also, in figure 3 the obtained regressions show that the $\mathrm{pH}$ variations $\left(\mathrm{b}_{x y}\right.$ $\left.=0.0042, r^{2}=0.80, p<0.001\right)$, degradation rate $c$ $\left(\mathrm{b}_{x y}=0.0169, \mathrm{r}^{2}=0.31, \mathrm{p}<0.004\right)$ and lag time $\left(\mathrm{b}_{x y}\right.$ $\left.=-0.0007, r^{2}=0.83, p<0.001\right)$ are attributed to the protein contribution of $M$. alba foliage to silage.

\section{DISCUSSION}

\section{Chemical composition}

The increase in the content of dry matter, ashes and crude protein and decrease in fiber content in mixed mini silos, was attributed to the addition of the foliage of $M$. alba. The observed behaviour indicates that the contribution of protein, ashes as minerals and dry matter of mulberry was greater compared to the contribution of corn and that the contribution of fiber (NDF, ADF and hemicellulose) was lower. Tesfay et al. $(2017,2018)$ and Bo-Trabi et al. (2017) report that the foliar parts of $M$. alba have low fiber and high crude protein (> 18.0\%) content. Copani et al. (2016), Olorunnisomo and Adesina (2014) and Mafakher et al. (2010) observed the same behaviour in mixed mini silos with the use of the energy and protein raw material.

The $\mathrm{pH}$ is considered an important variable in silages. The $\mathrm{pH}$ variation not altering the normalized 


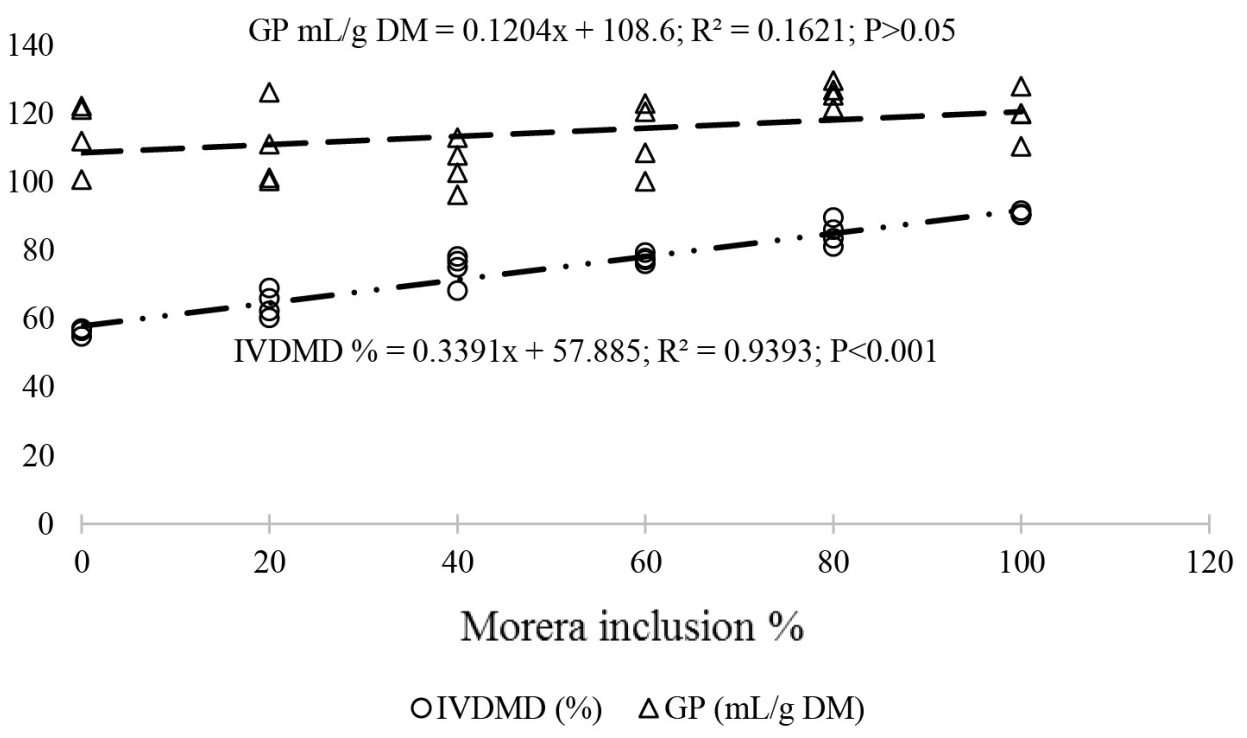

Figure 2. Regression analysis between the addition of Morus alba with the gas production (GP) and in vitro dry matter digestibility (IVDMD) of the maize plant silage.

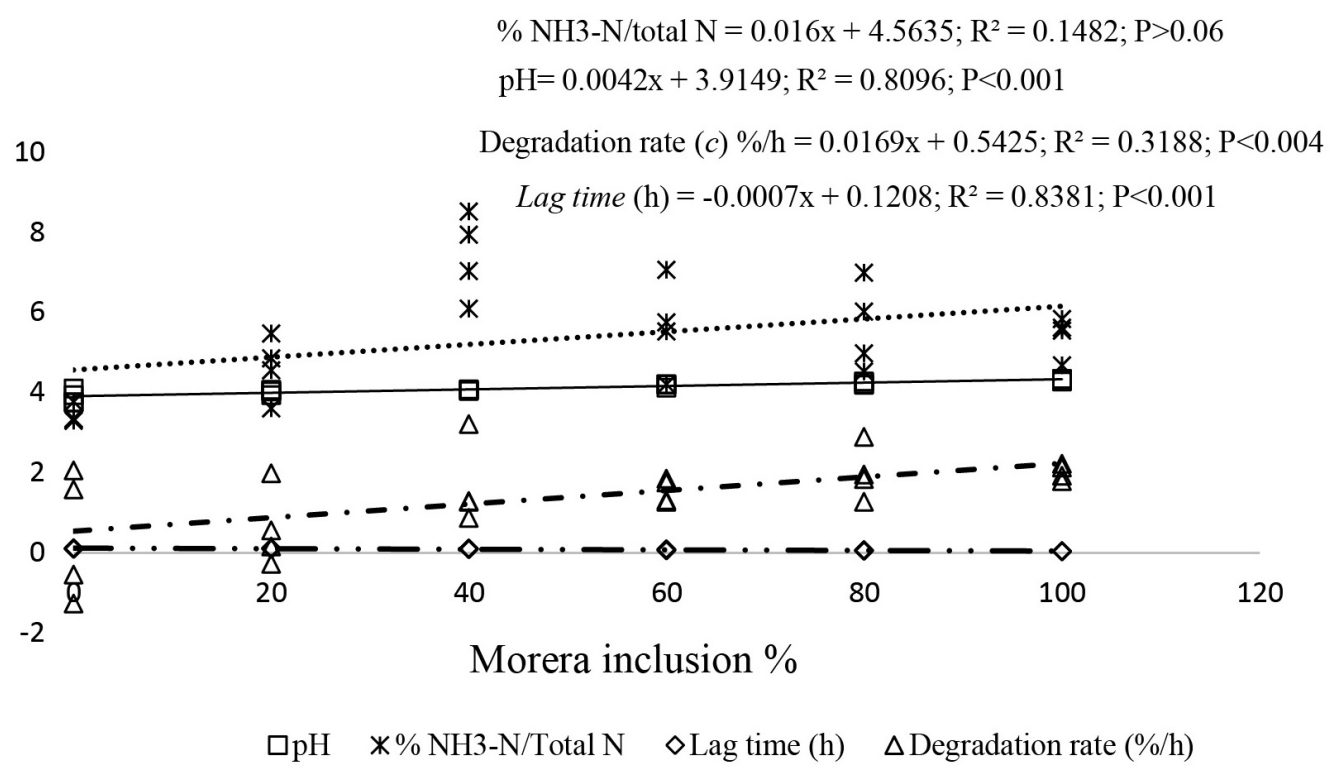

Figure 3. Regression analysis between the additions of Morus alba with the $\mathrm{pH}, \mathrm{NH}_{3}-\mathrm{N} / \mathrm{total} \mathrm{N}$, lag time and degradation rate $(\mathrm{c})$ of the maize plant silage.

values of acidity standardized for silages (3.5 to 4.5) (Copani et al. 2016). When the silage was $100 \%$ corn, the abundance of soluble carbohydrates resulted in a strong lactic fermentation by the bacteria which acidified the medium. The increase in $\mathrm{pH}$ in the silage was evident when the maize plant decreased from $100 \%$ to $40 \%$, with a proportional in- crease in mulberry foliage. This was attributed to the buffer effect exerted by the crude protein provided by the mulberry tree foliage (Table 2). The results match with several authors (Copani et al. 2016, Olorunnisomo and Adesina 2014, Hosoda et al. 2009) who report that the more acid pH (3.90) was obtained when the silage substrate was only energetic. Shito et al. 
(2005) reported that the silages are of a good fermentative quality when they have an average $\mathrm{pH}$ value of 4.0.

The greater IVDMD in the mini silos with 80 and $100 \%$ mulberry was attributed to the lower fiber contribution and higher crude protein from the tree foliage that gave the substrate greater digestibility (Table 2). Similar results were described by ContrerasGovea et al. (2011) in mixed silages of sorghum with Lablab seed. Reports indicate that in mixed silages, digestibility values can be improved depending on the tree species and/or legume used, as well as the proportion within the mixture (Cárdenas et al. 2003).

The ammonia levels of $7.40 \%$ can be explained by the energy-protein contribution of the 40-60 mixture, which promoted bacterial activity as higher for protein degradation with the use of energy and intensified the microbial protein synthesis for cellular replication of the anaerobic microflora of the silage. The same trend was observed by researchers in mixed silages of grasses with legumes (Contreras-Govea et al. 2011, Foster et al. 2011). Lasmar et al. (2017) determined with a correlation of 0.73 that ammonia nitrogen levels were attributed to the chemical composition of silage. It is important to highlight that although the addition of $60 \%$ of $M$. alba to silage increased the levels of $\mathrm{NH}_{3}-\mathrm{N}$ / total $\mathrm{N}$, this compound did not significantly exceed the values for quality mixed mini silos (<7.70\%) (Copani et al. 2016). The ammonia levels in silages with the use of tree foliage can be controlled by the presence of condensed tannins and a low energy substrate that limit the solubility and use of plant proteins by bacteria (Dewhurst et al. 2010), which could have happened in this study in mini silos with $100 \%$ mulberry.

The highest in vitro gas production volume in silage with $80 \%$ of mulberry was attributed to bacterial activity and was related with the energy-protein contribution of silage substrate. The digestion processes developed on silage substrate by the microflora of ruminal liquid used are favoured by the protein (used by bacteria for synthesis of microbial protein) and carbohydrates (used by bacteria as an energy source for metabolic processes) present in the middle. Elghandour et al. (2015) mentioned that gas pro- duction is generally a good indicator of digestibility, fermentability, and rumen microbial protein production, which correlated positively with feed digestibility.

In lag time (colonisation time) an average reduction of $0.038 \mathrm{~h}$ was observed in mixed mini silos with $80: 20$ and $60: 40 \%$ compared to $40: 60,20: 80$ and $0: 100 \%$ corn: mulberry, however, the final degradation rate (c) was the same in all silages. The increase in colonisation time was attributed to an imbalance in the contribution of energy and protein substrate when the proportion of mulberry (> 40\%) in silage was increased. The results show that it may be feasible to use mixed foliage of grasses and fodder trees in the silages preparation for animal feed in seasons of scarcity of forage. Tesfay et al. (2018) observed that the lag time of the feed substrate was greater when the concentrate was gradually substituted with M. alba foliage in dry matter basis. In a mixed silage of Pennisetum purpureum and Moringa oleifera (40 and $60 \%$, respectively) the nutritional value was also improved, and DM degradation increased (Gutiérrez et al. 2015).

\section{Association analysis between chemical composi- tion and degradation parameters}

The correlation between the content of dry matter and protein with the in vitro digestibility parameters indicated that a higher DM and protein content in the silages increased IVDMD and the $\mathrm{pH}$, similar to that reported by Castillo-Jiménez et al. (2009), Lasmar et al. (2017). In addition, the increase in $\mathrm{pH}$ is attributed to the fact that ammonia is one of the intermediate metabolites of the use of proteins at charge of silage bacteria.

The correlation analysis showed that at higher the fiber content (NDF, ADF and hemicellulose) lower the IVDMD, the $\mathrm{NH}_{3}-\mathrm{N}$ and degradation rate (c); that is, the decrease in digestibility of silages was justified in more of $90 \%$ to an increase in fiber content (Table 3), similar to that reported by Castillo-Jimenez et al. (2009) demonstrated in mixed corn silages with vigna, that increased acid and neutral detergent fiber and decreased IVDMD. It was also observed in regression analysis that the decrease of $-0.1623 \%$ ADF, $-0.1903 \%$ hemicellulose and the increase of $0.0555 \%$ 
$\mathrm{CP}$ in silages, was attributed in 93.28, 95.88 and $37.94 \%$ respectively to the mulberry addition (Figure 1), which significantly improved digestibility and fermentation parameters (figures 2 and 3 ) due to that the significant increase observed in the $\mathrm{pH}$ and degradation rate of the silages was attributed in a 80.96 and $31.88 \%$ to the mulberry addition and reduction in the colonization time (lag time) in $83.81 \%$ respectively.

\section{CONCLUSIONS}

It is concluded that the dry matter and nitrogen contributions of mulberry, diminish the fiber content and increase digestibility parameters of the silage when it is elaborated with $40-60$ parts of corn plant and mulberry, respectively.

\section{LITERATURE CITED}

AOAC (2000) Official methods of analysis. 17th edn. Association of Officiant Analytical Chemist. Arlington. 74p.

Behling NA, Pereira DRRH, Da Silva CL, Gonçalves DAJ, De Paula SD, Gama DSF (2017) Nutritional value of sorghum silage of different purposes. Ciência y Agrotecnología 41: 288-299.

Bo-Trabi E, Yuan X, Li J, Dong Z, Ali-Shah A, Shao T (2017) Effect of Glucose and Lactic Acid Bacteria on the Fermentation Quality, Chemical Compositions and in vitro Digestibility of Mulberry (Morus alba) Leaf Silage. Pakistan Journal of Zoology 49: 2271-2277.

Cárdenas MJV, Sandoval CCA, Solorio SFJ (2003) Composición química de ensilajes mixtos de gramíneas y especies arbóreas de Yucatán. Técnica Pecuaria en México 41: 283-294.

Castillo-Jiménez M, Rojas Bourillón A, WingChing-Jones R (2009) Valor nutricional del ensilaje de maíz cultivado en asociación con vigna (Vigna radiata). Agronomía Costarricense 33: 133-146.

Contreras-Govea F, Marsalis M, Angadi S, Smith G, Lauriault LM, VanLeeuwen D (2011) Fermentability and Nutritive Value of Corn and Forage Sorghum Silage When in Mixture with Lablab Bean. Crop Science 51: 1307-1313.

Copani G, Niderkorn V, Anglard F, Quereuil A, Ginane C (2016) Silages containing bioactive forage legumes: a promising protein-rich feed source for growing lambs. Grass and Forage Science 71: 622-631.

Dewhurst RJ, Davies LJ, Kim EJ (2010) Effects of mixtures of red clover and maize silages on the partitioning of dietary nitrogen between milk and urine by dairy cows. Animal 4: 732-738.

Dijkstra J, Kebreab E, Bannink A, France J, López S (2005) Application of the gas production technique to feed evaluation systems for ruminants. Animal Feed Science and Technology 123-124: 561-578.

Elghandour MMMY, Kholif AE, Bastida AZ, Martínez DLP, Salem AZM (2015) In vitro gas production of five rations of different maize silage and concentrate ratios influenced by increasing levels of chemically characterized extract of Salix babylonica. Turkish Journal Veterinary and Animal Science 39: 1-9.

Foster JL, Carter JN, Sollenberger LE, Blount AR, Myer RO, Maddox MK, Phatak SC, Adesogan AT (2011) Nutritive value, fermentation characteristics, and in situ disappearance kinetics of ensiled warm-season legumes and bahiagrass. Journal of Dairy Science 94: 2042-2050.

Gutiérrez D, Borjas RE, Rodríguez HR, Rodríguez Z, Stuart R, Sarduy L (2015) Evaluación de la composición química y degradabilidad ruminal in situ de ensilaje mixto con Pennisetum purpureum cv Cuba CT-169: Moringa oleífera. Avances en Investigación Agropecuaria 19: 7-16. 
Hosoda K, Eruden B, Matsuyama H, Shioya S (2009) Silage Fermentative Quality and Characteristics of Anthocyanin Stability in Anthocyanin-rich Corn (Zea mays L.). Asian-Australasian Journal of Animal Science 22: 528-533.

Khan, NA, Yu P, Ali M, Cone JW, Hendriks WH (2015) Nutritive value of maize silage in relation to dairy cow performance and milk quality. Journal Science Food Agriculture 95: 238-252.

Krishnamoorthy U, Soller H, Menke KH (1991) A comparative study on rumen fermentation or energy supplements in vitro L. Animal Physiology and Animal Nutrition 65: 28-35.

Lasmar DOI, Miranda LL, Rume CD, André SM, Fernandes BMT (2017) Nutritive value of corn silage from intensive dairy farms in Brazil. Revista Brasileira de Zootecnia 46: 494-501.

Luscher A, Mueller-Harvey I, Soussana JF, Rees RM, Peyraud JL (2014) Potential of legume based grasslandlivestock systems in Europe: a review. Grass and Forage Science 69: 206-228.

Macome FM, Pellikaan WF, Schonewille Th, Bannink A, Van Laar H, Hendriks WH, Warner D, Cone JW (2017) In vitro rumen gas and methane production of grass silages differing in plant maturity and nitrogen fertilization, compared to in vivo enteric methane production. Animal Feed Science and Technology 230: 96-102

Mafakher E, Meskarbashee M, Hassibi P, Mashayekhi MR (2010) Study of chemical composition and quality characteristics of corn, sunflower and corn-sunflower mixture silages. Asian Journal and Animal Veterinary Advances 5: 175-179.

Olorunnisomo OA, Adesina MA (2014) Silage characteristics, nutritive value and preference of zebu cows for moringa leaf ensiled with different levels of Cassava peel. Journal of Applied Agriculture Research 6: 191196

SAS (2002) SAS/STAT. Statistical Analysis System. Guide for personal computers version Ver 9.0. Institute Inc., Cary. USA. 956p

Shito H, Takahashi H, Shibuya Y, Yamana N (2005) Fermentation quality of silage ensiled by the roll baler for chopped materials. Japanese Journal of Grassland Science 51: 87-92.

Tesfay G, Tamir B, Berhane G (2017) Carcass and non-carcass characteristics of Tigray highland lambs fed mulberry (Morus alba) leaf meal at different supplementation levels. Journal of Scientific and Innovative Research 6: 104-109

Tesfay G, Tamir B, Berhane G (2018) Feeding value potential of mulberry (Morus alba) leaf meal to replace concentrate mix. International Journal of Livestock Production 9: 95-101.

Theodorou MK, Williams BA, Dhanoam MS, Mcallan AB, France J (1994) A simple gas production method using a pressure transducer to determine the fermentation kinetics of ruminant feeds. Animal Feed Science and Technology 48: 185

Van Soest PJ, Robertson JB, Lewis BA (1991) Methods for dietary fiber, neutral detergent fiber, and nonstarch polysaccharides in relation to animal nutrition. Journal of Dairy Science 74: 583-597 
